Тиха, Лариса. «Функційні особливості лексики на позначення кольору (на матеріалі перекладу роману Анджея Стасюка „Схід”)». Лінгвостилістичні студії, вип. 14, 2021, с. 135-43.

Tykha, Larysa. "Functional Features of the Vocabulary for Color Designation (a Case Study of the Translation of the Andrzej Stasyuk's Novel “East” )". Linguostylistic Studies, iss. 14, 2021, pp. 135-43.

Удк 811.161.2'373

https://doi.org/10.29038/2413-0923-2021-14-135-143

\title{
ФУНКЦІЙНІ ОСОБЛИВОСТІ ЛЕКСИКИ НА ПОЗНАЧЕННЯ КОЛЬОРУ (НА МАТЕРІАЛІ ПЕРЕКЛАДУ РОМАНУ АНДЖЕЯ СТАСЮКА «СХІД»)
}

\author{
Лариса Тиха \\ Луцький національний технічний університет, \\ Луцьк, Україна
}

у статті проаналізовано функційні особливості слів-кольороназв, їх сполучуваність з іншими категоріями лексики та роль у творенні авторських художніх образів. Визначено найбільш продуктивні групи колористичної лексики, що вживається в тексті як у прямому значенні, виражаючи безпосередньо вказівку на колір, так і підкреслюючи емоційний стан персонажа, його внутрішній стан, ставлення до навколишнього світу. На основі проведеного аналізу з'ясовано, що в авторському тексті найбільш вживаними назвами кольорів виявилися відтінки зеленого, червоний, чорний, сірий (срібний).

Ключові слова: ідіостиль, кольороназви, семантичне поле, художній образ.

\section{FUNCTIONAL FEATURES OF THE VOCABULARY FOR COLOR DESIGNATION (A CASE STUDY OF THE TRANSLATION OF THE ANDRZEJ STASYUK'S NOVEL “EAST” )}

\author{
Larysa Tykha \\ Lutsk National Technical University, Lutsk, Ukraine
}

The article analyzes the linguistic features of Andrzej Stasiuk in terms of the stylistic meaning of the lexemes denoting color. A case study material is the translation of the novel "East". Andrzej Stasiuk is a modern Polish writer, whose prose depicts the real images and real pictures of life, which are often created through sounds, smell, and, especially, color. This distinguishing feature of the author's style, namely lexemes used for color nomination, has become the subject of this research work.

The emphasis is laid on the most productive groups of color names, which became the centers of the artistic image creation manner in the author's text. The study has revealed that particularly productive are the lexemes related to the green color. In general, we can argue that A. Stasiuk's prose is 'green'. It is commonly known that green is the color-symbol of life, youth, and hope. The writer uses it both in direct meaning (in depicting landscapes or even water objects) and figuratively (strengthening the impressions of certain events, the emotional state of the character, as a feature of the character).

The study has also identified a high frequency use of the lexeme red, which belongs to the spectrum of hot colors. A. Stasiuk uses it mostly in the direct meaning (describing fire,

(C) Тиха Л., Волинський національний університет імені Лесі Українки, 2021.

Це стаття відкритого доступу на умовах СC BY-NC 4.0 
sunset). Frequently, the epithet red is used to bring some emotional detail to the description in the text, thus, increasing the expressiveness of the whole novel.

Significant semantic and stylistic load in the works of A. Stasiuk falls on the adjective black. In the author's text, it is traditionally an attribute of evil, sorrow, and the like.

The use frequency of color-lexeme gray is insignificant. The study has revealed its usage in both direct and figurative meaning.

There are some examples with such color names as blue, brown, white, gold. They are mostly used in the metaphorical structures and in common word combinations. A small number of examples illustrate a group of words-characteristics: colorful, another color, particolored, sandy (all their use cases are in the direct meaning).

Key words: idiostyle, color names, semantic field, artistic image.

Вступ. У сучасній лінгвістиці актуальним $є$ дослідження індивідуальної мовної картини світу, зокрема мовної картини світу письменника, яка становить комплекс багатьох чинників: культурноісторичних, суспільно-політичних, індивідуально-психофізіологічних, художньо-виражальних, зумовлених традицією, тематикою тощо.

Відомо, що серед засобів передачі чуттєвого сприйняття i відтворення світу найбільш розвинене чітко структуроване семантичне поле кольороназв, яке відіграє важливу роль в естетичному сприйнятті (Тиха 81).

Найширше у лінгвістиці репрезентований аналіз кольороназв у системі мовно-виражальних засобів мови письменників. Це сприяє визначенню місця колористики в національній картині світу через дослідження зображально-відображальних можливостей кольоронайменувань в індивідуальних художніх мовних картинах світу майстрів слова.

Кольоронайменування $\epsilon$ одним із найвиразніших показників індивідуальності автора, розкриває особливості сприйняття й відображення ним мовної картини світу (Тиха 81).

Лінгвістична література постійно поповнюється новими дослідженнями лексичних, граматичних, стилістичних особливостей кольоронайменувань. Останні дослідження в українському мовознавстві репрезентовані працями О.Микитюк «Кольороназви як відтворення ідеології Дмитра Донцова», С. Шуляк «Ахроматичні кольороназви в текстах українських народних замовлянь», О. Кадочнікової «Кольороназви в текстах інтернет-видань для жінок: походження, семантика, функцї̈» (проаналізовано якісний склад лексико-семантичної групи назв кольорів, схарактеризовано компонентний склад мікросистем назв основних кольорів, описано шляхи їх поповнення), Т. Ткаченко «Лексико-граматична i стилістична параметризація колоративної лексики в мові роману В. Винниченка «Сонячна машина» (досліджено лексико-граматичні i стилістичні особливості колоративної лексики в мові роману В. Винниченка «Сонячна машина» як вияв індивідуального стилю письменника). 
Проблеми перекладу колоративів представлено у роботах таких авторів, як О. Паньків «Проблеми відтворення стилістичної семантики колірних лексем англійської мови в українських перекладах», Т. Венкель, 0. Венкель «Переклад кольороназв у рекламному тексті (на матеріалі реклами косметичної продукції)».

Колір (колоративна номінація) $\epsilon$ тим засобом, який залучає письменник для створення зримої, випуклої картини, цілісного словесного образу. Виконуючи свою переносно-зображальну функцію, метафоричні епітети створюють емоційний настрій, увиразнюють почуття. Зокрема, переносне вживання прикметників кольору сприяє поглибленню асоціативних образів, активізації творчої уяви читача (Тиха 82). Тож мета нашого дослідження - проаналізувати різні групи кольоронайменувань, їх сполучуваність 3 іншими групами лексики, участь у творенні індивідуально-авторських образів.

Матеріал і методи дослідження. Джерельною базою роботи стали авторські словосполуки із ключовими лексемами на позначення кольору, дібрані методом суцільної вибірки (роман «Схід» у перекладі Тараса Прохаська). Крім того, у дослідженні застосовані такі методи: метод компонентного аналізу для з'ясування семантичної структури опорних лексем; метод стилістичного експерименту застосовано для вивчення вмотивованості вибору певної групи колористичної лексики.

Результати дослідження та дискусія. Ідіостиль письменника не може бути достатньою мірою описаний без урахування того, що лексика на позначення кольору посідає в мовотворчості значне місце. Саме кольоронайменування $\epsilon$ найпоширенішою атрибутивною характеристикою широкого кола важливих для майстра слова образів, у тому числі й ключових, що наскрізно проходять через усю його творчість, вони $є$ тими «постійними організуючими, цементуючими елементами... носіями єдності в численних творах поета, елементами, що накладають на ці твори відбиток поетичної особистості... ці елементи вносять цілісність в індивідуальну міфологію поета» (П.Г. Пустовойт, 1974) (Тиха 81-82).

Зауважимо, що епітети, які виражають колір, є характерними для художньої мови загалом, а у прозі А. Стасюка вирізняються індивідуальністю, неповторністю, оригінальною сполучуваністю 3 іншими лексемами. Лінгвісти за наявністю палітри кольорів вирізняють письменниківграфіків (яким притаманне чорно-біле бачення) та письменниківживописців (які володіють багатою гамою кольорів) (Тиха 82). До останніх належить i Анджей Стасюк. Творчість Анджея Стасюка досить «кольорова». Письменник вживає кольороназви у прямому й переносному значенні 3 описово-зображальною та емотивно-оцінною, експресивною метою. Можна стверджувати, що колір для нього - спосіб вираження власного світобачення, сприймання навколишньої дійсності, реакції на певні життєві подразники. У нього часто асоціюються з певним колом понять відтінки зеленого, червоного, сірого, блакитного, чорного та ін. 
Прозу Анджея Стасюка сміливо можна назвати «зеленою». Традиційна символіка зеленого кольору пов'язана із життям, молодістю, свіжістю, надією. Зелений колір $є$ фізично нейтральним, оскільки він - барва біологічного середовища. У творчості польського письменника, як і в природі, цей колір представлений багато і різноманітно. Автор використовує зелений колір переважно у прямому значенні, для змалювання довкілля, наприклад: Справа починається низьке зелене пасовище зі стадами гусей (Стасюк 18), I віддалік Люблін, наче замок на зеленім узвишші, що оберігає спокій цих земель (Стасюк 21), Зелені і сірі смуги наділів впорядковують плаский простір (Стасюк 26), Зелена вода стояла у мертвих городах, а потім відходила, і залишалися багна (Стасюк 5).

Назва зеленого кольору служить в авторських текстах для створення пейзажів, на тлі котрих відбуваються певні політичні і суспільні події, для опису природи, зокрема водних об'єктів. Проте в таких випадках автор не завжди використовує назву так званого «чистого» кольору, часом це його відтінки, часом поєднання кількох кольорів: Буг завжди був зелений. Навіть під голубим небом (Стасюк 26), Здавалося, що земля трохи опускається в бік ріки, а потім, уже на другому березі, знову піднімається, зелена і безлюдна (Стасюк 26), Я вибирав ці краї, бо вони були зелені, просяклі золотим світлом і здавалося, що їх ніколи не покидає спека (Стасюк 21), Я тоді їхав з Бещад. Із зеленої, чудової країни, яка теж була підбита жахом минулого (Стасюк 21), Лагідні хребти узгір'я котяться на схід до кордону. Перемінно ясно-зелені і коричневі, поділені геометрією меж на клаптики (Стасюк 17), Нагробні лампадки тоді були із грубого скла. Зелені, червоні, білі (Стасюк 17).

Значно розширюється семантика вживання зеленого кольору у прикладах, де його назва бере участь у творення певного тропа, найчастіше це метафора або порівняння: Цілий день ми їхали електричкою без купе. Сім або вісім годин. Час до часу ми зупинялися у місиях, де безкрайня зелена оболонка на мить тріскала, і з-під неї виростали землянисті забудови (Стасюк 6), Зелені сутінки літа і крики у темноті (Стасюк 2), Довкола простягалася зелена пустка (Стасюк 3 ).

Художні образи, в яких ключовим словом виступає зелений колір, також позначені складною асоціативністю, крім того, спостерігаємо розгортання художнього образу у більш складну картину, наприклад: Віддалік стояв зелений ліс. Цемент, стара бляха і військова зелень мокрих дерев у світанковому освітленні (Стасюк 4), Прямокутник паперу зелений (карта. - Л. Т.), а десь більш-менш посередині цей залив. Як ляпка ясно-блакитного чорнила. Вище, вгорі карти, нема вже майже нічого, крім зеленого. Чорні иятки означають отдєльние строєнія, поодинокі будівлі (Стасюк 4).

3 прикладів бачимо, що основою художніх образів $\epsilon$ не тільки назва кольору, граматично виражена прикметником, але й відприкметниковим іменником: Буг простягає свої зелені рамена вздовж старого шосе, крізь 
цей одноповерховий край, жадібний втіхи, $а$ я вислуховую на ультракоротких хвилях диявольську, ненависну бесіду, що ведеться в ім'я релігії, яка стверджує, що «спочатку було слово» (Стасюк 19), Їдеш щораз далі на південь, і зелень повільно зникає. Жовтіє і набуває піщаної барви (Стасюк 67). Ось як письменник описує дорогу російськими містами: Bid присілка до присілка було п'ятнадиять, двадиять кілометрів. Сіре дерево, шифер і штахетні паркани, двадиять кілометрів зелені - $і$ знову сіре дерево, двосхилі шиферні дахи і ці штахети, що захищають картоплю (Стасюк 36).

Творчість Анджея Стасюка наповнена і червоними тонами, хоча не настільки повно і насичено, як, наприклад, зеленими. Червоний колір відноситься до підгрупи назв гарячого спектру. У прозі А. Стасюка містить переважно пряму вказівку на колір. Це, зокрема, пейзажна характеристика або означення певного об'єкта: Cилует голих гір, червоний вогонь $\boldsymbol{i}$ небо (Стасюк 67), В домі під червоною табличкою він (дідусь) відправляв маївки до Пресвятої Богородиці (Стасюк 75), Під червоними накривками на червоних папірчиках лежали два білі браслети з пластику, що імітував алебастр (Стасюк: 64), Впевнений, що того ранку, коли я вперше опинився в цьому місті, небо на сході було червоне (Стасюк 21), Біля одного (хреста) горіла червона намогильна лампадка (Стасюк 17), Так я собі роздумував, вдивляючись у червоні світла авто, які мене обганяли (Стасюк 17).

Неодноразово спостерігаємо вживання червоного кольору у поєднанні 3 іншими для відтворення реалій зовнішнього світу, для передачі політичних вподобань персонажа: Не відомо, чи на ньому була червона зірка, чи біло-червона шахівниця (Стасюк 9), Тоді не було ... Зелених, червоних, синіх і жовтих лопат, оббитих алюмінієм (Стасюк 5).

Інколи за допомогою такого прийому прозаїк передає власну позицію щодо тих чи тих подій: Вийшов і відразу побачив цей червоночорний напис: «Засоби гігієни. Імпорт з Німеччини». Його намалювали пензлем або спреєм на двоповерховому будинку з великим цегляним комином. Відразу за парканом концтабору. Зо півгодини я ходив і відгортав мокрий сніг з написів польською і гебрейською. Відшукав місия, в яких бував: Дукля, Золочів, Риманув, Делятин. По-польськи і по-гебрейськи. Але треба було згортати мокрий сніг з кам'яних плит, щоб відслонити літери. Весь час із цим написом за спиною, що гігієна - з Німеччини (Стасюк 22), Це умирання, розкладання під небом не давало мені спокою. Колись я бачив фотографії з похорону в Непалі. Монахи у червоних шатах четвертували тіло. Ножами оббирали з нього м'ясо. На руках мали латексні рукавички. Жбурляли червоні обрізки у повітря. Грифи хапали їх в польоті (Стасюк 66).

Значне семантичне і стилістичне навантаження у творах А.Стасюка припадає на прикметник чорний. У християнській символіці ця кольороназва $\epsilon$ атрибутом темних сил, зла, гріховності, горя, негативу. I хоча у прозі А.Стасюка він не позначений особливою частотністю вживання, все ж виконує важливу роль для створення художніх образів: 
Серед заростей стояла чорна, прозора вода (Стасюк 13), Впевнений, що того ранку, коли я вперше опинився в цьому місті, небо на сході було червоне. Алебарди замкового декору на цьому тлі виглядали чорно і грізно (Стасюк 21), Чорні сокири нависали над Сходом як прокляття, як погроза (Стасюк 21), ...вогники випалювали щоденність, яка звуглювалася, чорніла на краях $і$ згорталася, як підпалений папір, аби показати... що саме? (Стасюк 62).

Цікаві образи автор створює поєднанням чорного і жовтого кольорів, наприклад: Розклад рейсів хтось каліграфічно понаписував чорною нітратною фарбою на маленьких жовтих табличках (Стасюк 12), Вона не має поняття, як тут тепер, але ж якось уявляє собі те місце, звідки ми від'їжджали голубим «Єльчем» сорок років тому. Всі ті жовті і чорні зі своїми товарами, з гамором своїх мов, тією своєю чужістю, якої вона здалека боїться, проникають, немов напівпрозорий образ, поміж нею і тими днями, коли ми з фібровою валізкою чекали автобуса (Стасюк 12), Туди, де в дерев'яному домі жовтий промінь нафтової лампи пропалював чорний папір ночі, а на звороті цієї випаленої сторінки з'являлися неспокійні сни, яких не зберегла пам'ять, але нічого важливішого після них більше ніколи не снилося (Стасюк 21).

До семантичного поля чорного кольору належить також епітет темний. Авторські образи, ключовим словом у яких постає така кольороназва, підсилюються контрастною лексемою (тут червоний): $У$ темному залі показували виставу про народні страхи. Чорти і відьми світилися червоним (Стасюк 22).

Незначною частотністю використання позначений і сірий колір. Його вживання зафіксоване і з прямим, і з переносним значенням: Сipi ранішні люди стояли на зупинках (Стасюк 25), Сірий дощ падав на сірий бетон (Стасюк 4), У селах із сірого дерева, в хатах під стріхами, серед піщаних городів чаївся страх перед диким, незліченним і захланним, яке насунеться, пограбує і пустить з димом ті піски, стріхи і халупи, не набагато кращі за монгольські юрти (Стасюк 5) (про колективізацію, комунізм, соціалізм), який здебільшого вживається у поєднанні з іншими кольорами: Від присілка до присілка було п'ятнадиять, двадиять кілометрів. Сіре дерево, шифер і штахетні паркани, двадиять кілометрів зелені - і знову сіре дерево, двосхилі шиферні дахи і ці штахети, що захищають картоплю (Стасюк 36), Один віз вифлеємську зірку на патику. Вона була із сірого картону, ще не позолочена. Мала колір землі і луків (Стасюк 27), Зелені і сірі смуги наділів впорядковують плаский простір (Стасюк 26), Те, що людське, тут потрохи трухлявіє і повільно розвалюється. Силікатна цегла, коричнева деревина. Чорне, біле, сіре (Стасюк 15), Пакунки мали той же колір, що й папір. Сірі, білі, бурі з вищвілими написами (Стасюк 9).

Близьким за значенням до сірого кольору $є$ найменування срібний (сріблястий). У своєму тексті автор використовує його для змалювання стану природи: Повітря ставало срібним і вологим (Стасюк 9), Срібна 
сяйлива вода витікає з глибин землі, з глибини цього краю, враженого неврозом, пожертого істерією (Стасюк 15).

Окремими прикладами представлені такі колористичні найменування у складі метафоричних структур та загальномовних поєднань лексем, як блакитний (голубий): У ліжку було сонно і тепло, але досить висунути долоню - і відчуваєш ясний, блакитний холод (Стасюк 6), Сіро-блакитне світло ранку наповнює кімнату. Це сяйво таке саме, як у дитинстві в неділю чи на канікулах, коли можна довше залишатися у ліжку, сам на сам $з$ фантазіями про всі прийдешні світи (Стасюк 6), Буг завжди був зелений. Навіть під голубим небом (Стасюк 26), Я вийшов і пішов до ріки. Вона була сіро-блакитна... (Стасюк 15), Але тоді було порожньо. Лишень у час від'їзду, за півгодини до від'їзду голубих автобусів на бетонних платформах збирався натовп (Стасюк 12); коричневий, білий, золотистий: Коричневий папір для пакунків імітував скелі, але білі квіти у вазонках здавалися живими (Стасюк 19), Те, що людське, тут потрохи трухлявіє $і$ повільно розвалюється. Силікатна цегла, коричнева деревина (Стасюк 15), Лагідні хребти узгір'я котяться на схід до кордону. Перемінно ясно-зелені $\boldsymbol{i}$ коричневі, поділені геометрією меж на клаптики (Стасюк 17); Великі селянські кошики, накриті білими серветками (Стасюк 17); Від золотистих буханців ставало ще світліше (Стасюк 9).

Індивідуальна мова Анджея Стасюка поповнила мову художньої літератури такими образами, в яких автор спочатку використовує загальну назву на позначення спектру кольорів, а потім ніби «розшифровує» його. Такі образні структури набувають сильнішого звучання, стають більш видимі і передають найтонші враження автора від реалій світу. Йдеться передусім про такі найменування, як монохромний, кольоровий тощо: Тоді не було пластикового кольорового знаряддя. Зелених, червоних, синіх і жовтих лопат, оббитих алюмінієм. Лишень бура фанера і почорнілий метал (Стасюк 5), Монохромна матерія. Білі, геометричні площини дахів і сірий дим, що підіймався просто в небо (Стасюк 5), Я знав ці обличчя. Запам'ятав їх з радянських фільмів, побачених у дитинстві. Вони зовсім не змінилися. Тільки тепер були кольоровими, а тоді чорно-білими (Стасюк 6).

В окрему групу виділяємо приклади авторських художніх образів, побудованих на нанизуванні, поєднанні різних кольорів, як-от: Там, уже всередині тієї алеї, згушувалися і повітря, і світло, і форми, і барви. Це було настільки барвисте і розмаїте, що не до порівняння ні з чим. Нічого подібного тоді на світі не було. Немов входиш посеред ясного дня прямо до печери з дивами. У півтемряву, де сяяло, вабило і мерехтіло. Фіолетовим, смарагдовим, рубіновим, пурпуровим, лазуровим, туркусом, сапбіром, золотом, сріблом, ладаном і миром (Стасюк 59), Жовті, помаранчеві, фіолетові і червоні вогники випалювали щоденність, яка звуглювалася, чорніла на краях і згорталася, як підпалений папір, аби показати... що саме? (Стасюк 62), Те, що людське, тут потрохи трухлявіє і повільно 
розвалюється. Силікатна цегла, коричнева деревина. Чорне, біле, сіре (Стасюк 15), Нагробні лампадки тоді були із грубого скла. Зелені, червоні, білі (Стасюк 12), Пакунки мали той же колір, що й папір. Cipi, білі, бурі 3 вицвілими написами. Кисіль, пудинг, цукор, сіль (Стасюк 9), Я не міг відірвати погляду від цих хлопців у тамбурі. Вони виглядали так, ніби вдягалися напотемки. Жовте з біолетовим. Рожеве з голубим (Стасюк 6).

Незначною кількістю прикладів представлена група слівхарактеристик: кольоровий, інший колір, барвистий, піщаний (фіксуємо вживання їх у прямому значенні): Навіть тоді, коли ї̈ не видно, повітря над нею має інший колір, воно чистіше, і відчувається запах тисячолітніх мілин (Стасюк 15), Придорожні хрести хтось прибрав кольоровими (Стасюк 17), зелень ... набуває піщаної барви (Стасюк 67).

Висновки та перспективи дослідження. Проведене дослідження дозволяє зробити висновки, що новизна у вживанні А.Стасюком колористичних прикметників помітна, адже тут і традиційні засоби їх використання (пряма вказівка на колір), і суб'єктивне сприймання кольору. У його творах оновлюються, постають по-новому давно відомі лексичні засоби, які допомагають дивитися на описувані події одночасно й очима автора, і сприймати ці події, зважаючи на власний життєвий досвід. Проте на основі перекладу лише одного роману автора важко зробити однозначні висновки про функційні можливості кольороназв, тому тема потребує подальшого ретельного аналізу.

\section{Список використаної літератури}

Венкель, Тетяна, і Венкель, Олена. Переклад кольороназв у рекламному тексті (на матеріалі реклами косметичної продукції). URL: http://www.chnu.edu.ua/res/ chnu.edu.ua/period_vudannia/web13/pdf/2011_3/Tetiana_Venkel_Olena_Venkel.pdf

Кадочнікова, Олена. «Кольороназви в текстах інтернет-видань для жінок: походження, семантика, функції». Наукові записки НаУКМА. Мовознавство, т. 1, 2018, с. 50-7.

Микитюк, Оксана. Кольороназви як відтворення ідеології Дмитра Донцова. Лінгвостилістичні студії, вип. 4, 2016, с. 144-53.

Паньків, О. Проблеми відтворення стилістичної семантики колірних лексем англійської мови в українських перекладах Науковий вісник Волинського національного університету імені Лесі Українки, вип. 22, 2012, с. 173-8.

Петращук, Микола. Про Схід як феномен - новий роман Анджея Стасюка. URL: https://vsiknygy.net.ua/shcho_pochytaty/45232/

Стасюк, Анджей. Схід. Львів: Видавництво Старого Лева, 2015.

Ткаченко, Тетяна, і Горяінова, Віталіна. «Лексико-граматична і стилістична параметризація колоративної лексики в мові роману В. Винниченка «“Сонячна машина”». Науковий часопис Національного педагогічного університету імені М. П. Драгоманова. Серія 8: Філологічні науки (мовознавство і літературознавство), вип. 10, 2018, c. 3-7.

Тиха, Лариса. Метафора в поетичному дискурсі Івана Драча. Дис. ...канд. філол. наук: 10.02.01. Київ, 2007.

Українська мова: енциклопедія, за ред. ред. В. М. Русанівського, і О. О. Тараненка. 3-тє вид. Київ, 2007. 
Хохулин, Александр. Анджей Стасюк: Украинскость - это подсознание польскости. URL: https://zaxid.net/andzhey_stasyuk_ukrainskost_eto_podsoznanie_polskosti_ n1188182

Шуляк, Світлана. «Ахроматичні кольороназви в текстах українських народних замовлянь». Наукові записки Центральноукраїнського державного педагогічного університету ім. В. Винниченка. Серія: Філологічні науки, вип.175, 2019, с.554-8.

Stasiuk, Andrzej. Wschód. Czarne, 2014.

\section{References}

Venkel, Tetiana, and Venkel, Olena. Pereklad koloronazv u reklamnomu teksti (na materiali reklamy kosmetychnoi produktsii). www.chnu.edu.ua/res/chnu.edu.ua/period_ vudannia/web13/pdf/2011_3/Tetiana_Venkel_Olena_Venkel.pdf

Kadochnikova, Olena. "Names of Colors in the Texts of Online Editions for Women: Origin, Semantics, Functions". NaUKMA Research Papers. Linguistics, vol. 1, 2018, pp. 50-7.

Mykytiuk, Oksana. "Colour Term lexemes as Reproduction of Dmytro Dontsov's Ideology". Linguostylistic Studies, iss. 4, 2016, pp. 144-53.

Panjkiv, 0. "The Problems of Rendering of Stylistic Semantics of English Color Lexemes in the Ukrainian Translations". Naukovyi visnyk Volynskoho natsionalnoho universytetu imeni Lesi Ukrainky: Filolohichni nauky. Movoznavstvo, iss. 22, 2012, pp. 173-8.

Petrashchuk, Mykola. Pro Skhid yak fenomen - novyi roman Andzheia Stasiuka, vsiknygy.net.ua/shcho_pochytaty/45232/

Stasiuk, Andzhei. Skhid. Lviv: Vydavnytstvo Staroho Leva, 2015.

Tkachenko, Tetyana, and Horiainova, Vitalina. "Lexical-grammatical and stylistic parametrization of colorative vocabulary in novel's language V. Vynnychenko "Solar machine"'". Naukovyi chasopys Natsionalnoho pedahohichnoho universytetu imeni M.P.Drahomanova, seriia 8: Filolohichni nauky (movoznavstvo i literaturoznavstvo), iss. 10, 2018, pp. 3-7.

Tykha, Larysa. Metafora v poetychnomu dyskursi Ivana Dracha. PhD Thesis. Kyiv, 2007.

Ukrainska mova: entsyklopediia, edited by V. M. Rusanivskyi, and 0. O. Taranenko. $3^{\text {rd }}$ ed. Kyiv, 2007.

Hohulin, Aleksandr. Andzhej Stasjuk: Ukrainskost' - jeto podsoznanie pol'skosti, zaxid.net/andzhey_stasyuk_ukrainskost_eto_podsoznanie_polskosti_n1188182

Shuliak, Svitlana. "Achromatic Names of Colours in the Texts of Ukrainian Folk Spells". Research Bulletin Volodymyr Vynnychenko Central Ukrainian State Pedagogical University. Series: Philological Sciences, iss. 175, 2019, pp. 554-8.

Stasiuk, Andrzej. Wschód. Czarne, 2014.

Стаття надійшла до редколегії 06.03.2021 